\title{
SIFRÁ Y PUÁ: VALIENTES, REBELDES Y SABÍAS HEROÍNAS. LA FIGURA Y EL ACCIONAR DE LAS PARTERAS EN EX 1, 15-22 1
}

Shiphrah and Puah: brave, rebellious and wise heroines. The figure and actions of midwives in Ex 1, 15-22

\author{
FACUndo Mela, FDP²
}

\section{Resumen}

Tras el relato de los inicios de la esclavitud sufrida en Egipto, Ex 1, 15-22 narra cómo dos valientes parteras, Sifrá y Puá, movidas por el temor de Dios, desobedecen la orden de asesinar a los varones hebreos recién nacidos. Sus intrépidas e inteligentes acciones impiden el infanticidio y se transforman en causa de bendición para el pueblo y para ellas mismas. Estas heroínas se embarcan en un combate desigual y vencen a un monarca todopoderoso que quiere destruir al Pueblo de Dios, convirtiéndose en un ejemplo de lucha contra la cultura de la muerte y el descarte. En un mundo que da la espalda a los inmigrantes y donde aún existen limpiezas étnicas y genocidios, ellas se alzan como prototipos de mujeres de fe comprometidas con los sufrimientos de los pobres y los excluidos. Llamativamente, la tradición bíblica no recordó su valiente epopeya; por el contrario, la tradición rabínica y las leyendas hebreas sí lo hicieron. Este artículo se propone recuperar las figuras de Sifrá y Puá, estudiando detenidamente distintos aspectos de estas excepcionales mujeres, tales como el oficio de la comadrona en la Antigüedad, la posesión de nombres, la cuestión de su nacionalidad, las temerarias acciones que llevaron a cabo, el temor de Dios y la sabiduría que poseían, su transformación en instrumentos de la Providencia, la bendición obtenida, la astucia y el coraje, la maternidad, la resistencia ante la opresión, su sororidad, etc. Para el análisis, se aplicarán distintas instancias del método histórico crítico, la narratología, la interpretación rabínica y otras aproximaciones.

1 Artículo de reflexión sobre la figura y el accionar de las parteras Sifrá y Puá en Ex 1, 15-22.

2 Licenciado en Teología con especialización en Sagrada Escritura por la Pontificia Universidad Católica Argentina. Correo electrónico: facundofdp@yahoo.com.ar. 


\section{Palabras clave:}

Antiguo Testamento; Éxodo; Interpretación rabínica; Mujer; Parteras.

\section{Abstract}

After the account of the beginnings of slavery suffered in Egypt, Ex 1: 15-22 narrates how two brave midwives, Shiphrah and Puah, moved by the fear of God, disobeyed the order to kill the newborn Hebrew males. Their intrepid and intelligent actions prevent infanticide and become a cause of blessing for the people and for themselves. These heroines embark on an unequal combat and defeat an all-powerful monarch who wants to destroy the People of God, and they become an example of the struggle against the culture of death and discarding. In a world that turns its back on immigrants and where ethnic cleansings and genocides still exist, they stand as prototypes of women of faith committed to the sufferings of the poor and the excluded. Remarkably, the biblical tradition did not recall their valiant epic; on the contrary, rabbinical tradition and Hebrew legends did. This article aims to recover the figures of Shiphrah and Puah, by carefully studying different aspects of these exceptional women, such as the office of midwife in ancient times, the possession of names, the question of their nationality, the reckless actions they carried out, the fear of God and the wisdom they possessed, their transformation into instruments of Providence, the blessing obtained, their cunning and courage, motherhood, resistance to oppression, their sisterhood, etc. For the analysis, different instances of the critical historical method, narratology, rabbinic interpretation and other approaches will be applied.

\section{Keyword:}

Old Testament; Exodus; Rabbinical interpretation; Woman; Midwives.

\section{Introducción}

Ex 1, 15-22 relata cómo dos parteras, Sifrá y Puá, movidas por el temor de Dios, desobedecen las órdenes infanticidas del rey de Egipto. Su valiente e inteligente accionar impide el asesinato de los varones hebreos recién nacidos y se transforma en causa de bendición para ellas y el pueblo.

Llamativamente, la tradición bíblica nunca las recordó, como tampoco su accionar. Incluso la perícopa de Ex 1, 15-22 tuvo poco eco en la Sagrada Escritura, solo unas muy breves alusiones (Sb 11, 6-7; 18, 5, Mt 2, 16-18; Hch 7, 18-19 y Hb 11, 23). Esto es mucho más evidente si se compara con la perícopa precedente, el relato de la opresión en Egipto (Ex 1, 8-14), y la siguiente, el nacimiento y crianza de Moisés (Ex 2, 1-10). Por el contrario, la literatura rabínica rescató del olvido a estas valientes mujeres. 
Este trabajo analiza su figura y accionar tal como son presentados en el texto canónico y en la tradición rabínica, ${ }^{3}$ como también hace uso de distintas aproximaciones para profundizar en su persona, su oficio, sus acciones y las consecuencias beneficiosas para la comunidad de Israel.

\section{El texto}

Se puede establecer con facilidad que Ex 1, 15-22 conforma una unidad literaria con una relativa autonomía respecto de los textos que la preceden y continúan. El libro del Éxodo comienza con el relato de la multiplicación de los descendientes de Jacob en Egipto (1, 1-7), la ascensión de un nuevo rey, la cruel opresión impuesta por este sobre aquellos y el continuo crecimiento del pueblo israelita (1, 8-14). Los personajes son los hijos de Jacob y su progenie, el rey de Egipto, el pueblo egipcio y los capataces.

En el versículo 15, comienzo de la perícopa, pese a que no hay cambio de tiempo y espacio, se introducen nuevos personajes: por una parte, las parteras, Sifrá y Puá, quienes serán receptoras de una nueva orden del rey de Egipto contra los hijos de Israel, una orden que ellas no cumplirán; por otra, Dios, quien actúa a favor de ellas. Finalmente, pese a que mantiene el tema de la perícopa anterior, limitar la multiplicación de los hebreos, el mecanismo para llevarlo a cabo es diferente.

En Ex 2,1, aparece un cambio de personajes, de tema e, implícitamente, de tiempo. Se relatan las vicisitudes que rodearon el nacimiento de Moisés. Los personajes son los padres y la hermana de Moisés, la hija de faraón y sus doncellas, y Moisés. No hay una vinculación explícita con el episodio de las parteras.

Por ello, en vista de lo analizado, se puede afirmar que Ex 1, 15-22 forma una unidad de sentido y que actúa como una "perícopa puente" entre 1,1-14 y 2, 1-10, ${ }^{4}$ pero no exenta de tensiones, incongruencias y cuestiones no resueltas del todo. ${ }^{5}$

3 Solo dos apócrifos del Antiguo Testamento, el libro de los Jubileos y Antigüedades Bíblicas, recepcionan partes de Ex 1, 15-22, pero no mencionan las parteras. En la versión siríaca del evangelio árabe de la infancia, único apócrifo del Nuevo Testamento que contiene ecos del texto estudiado, solamente se narra cómo el faraón persigue a un varón recién nacido hebreo: Jesús.

4 "La unidad podría ser dividida en tres partes. Ex 1, 1-14 introduce los 'hijos de Israel' al lector y describe cómo era el tratamiento de estos en la tierra de Egipto. Ex 1, 15-22 sirve como puente y muestra al faraón complotando para destruir a los hijos de Israel utilizando a las parteras. Ex 2, 1-10, que está en equilibrio con 1, 1-14, se focaliza en un hijo de Israel y muestra cómo el intento de genocidio lo afecta" (Wicke, 1982, p. 99).

5 Si el rey de Egipto esclavizó a los hebreos y luego mandó asesinar a los varones recién nacidos, ¿era consciente que luego se quedaría sin esclavos?, ¿por qué las niñas quedan con vida? y ¿en el futuro se mezclarán con los egipcios para dar prole? Durante el parto de Moisés, su madre no es ayudada por las comadronas. ¿Es esto una omisión voluntaria, un descuido redaccional o son textos de tradiciones distintas? ¿O tal vez el redactor recordó que las hebreas más vigorosas dan a luz antes de que llegue la partera (Ex 1, 19)? 


\section{Sifrá y Puá, heroínas de Israel}

Metodológicamente, se desarrollarán los distintos temas siguiendo el orden del texto bíblico, presentando, primero, los datos exegéticos; luego, las tradiciones rabínicas, y, finalmente, los aportes de los distintos enfoques y aproximaciones.

\section{Las parteras}

En el versículo 15, sorprende que el contenido de la orden del faraón no sea expresado inmediatamente. Este aparece recién en el versículo siguiente. El texto se explaya en las destinatarias de la orden: las parteras.

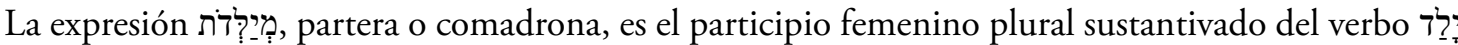
en piel, cuyo significado es "asistir partos" (v. 16). Este se sustantiviza como "aquella que asiste los partos" (vv. 15-21), por lo cual se traduce por "partera, comadrona” (Alonso, 1994, p. 317).

La raíz ילד, la cual recorre todos los versículos de la perícopa estudiada y aparece doce veces, es indicio de su relevancia. Su sentido está relacionado con el nacimiento: "parir" en qal (v. 19), "ayudar en los partos" en piel, como ya se señaló; "niño" o "bebé" (vv. 17-18) y el adjetivo "nacido" (v. 22).

En cuanto al uso del término partera en la Sagrada Escritura, aparecen nueve menciones: dos en singular y siete en plural. La primera mención en singular está en Gn 35, 17, en el contexto del nacimiento de Benjamín y la muerte de Raquel. La segunda en Gn 38, 28, en el relato del nacimiento de los mellizos de Tamar y Judá, su suegro. En ambos casos, las parteras son anónimas y se encuentran llevando a cabo su oficio durante un parto, sin ningún rol protagónico, ni relevante en los relatos.

En el caso de las siete menciones en plural, todas se encuentran en el texto analizado, seis veces refiriéndose explícitamente a Sifrá y Púa (Ex 1, 15, 17-21) y una de modo general (Ex 1, 19); ninguna de ellas se encuentra estrictamente en el contexto de un parto (a diferencia de las del Génesis). Esto muestra la importancia que tienen en el relato como protagonistas principales de la historia, y que el acento no está puesto en el modo en que desempeñan su oficio, sino en su actuar movidas por el temor de Dios. Ellas no solo ayudan a dar a luz, sino a que la vida llegue a ver la luz.

\section{El oficio de la comadrona}

En Ez 16,4, se hace referencia a la historia simbólica de Jerusalén, y se enumeran algunos de los cuidados que daban las comadronas a los recién nacidos: "Cuando naciste, el día en que viniste al mundo, no se te cortó el cordón, no se te frotó con sal, ni se te envolvió en pañales”. 
En cuanto respecta al oficio de las parteras en la Antigüedad, existe una gran variedad de artículos con diversas perspectivas: arqueológica, ${ }^{6}$ bíblica ${ }^{7}$ y médica. ${ }^{8}$ Ciertamente, estos trabajos son de gran ayuda para una mejor comprensión de los alcances de su oficio, como de sus conocimientos y técnicas.

Un dato de relevancia para el análisis es que las comadronas "probablemente eran mujeres mayores que poseían mucha experiencia en el parto" (Ebeling, 2010, p. 126), y "en términos generales las parteras eran mujeres post-menopáusicas, pues estaban ya libres de muchas restricciones de tiempo y pureza que afectaban a mujeres más jóvenes, y posiblemente muchas de ellas eran esclavas” (García, 1999, p. 15). Esto da mayor ironía al relato. Hay una sutileza, ellas ya eran posmenopáusicas, pero seguían dando vida con valentía e ingenio, por oficio y por convicción religiosa. La naturaleza nos les permitía dar a luz, pero ellas seguían haciéndolo, siendo una luz de esperanza para el pueblo oprimido.

Sin embargo, surge una objeción ante esto, ya que en Ex 1,21 se lee que Dios "les dio descendencia". Ante todo, se debe recordar que el texto no es una crónica histórica, sino un relato folclórico de gran simplicidad (Cassuto, 1967, pp. 14-15). La descendencia o las casas que Dios les otorgó podrían ser hijos, lo cual indicaría que aún estaban en edad reproductiva (aunque fueran mujeres maduras), un milagro en que mujeres estériles dan a luz (un motivo bíblico muy común) o también podría pensarse que el pueblo se transforma en su descendencia, y así en madres de los hijos de Israel y merecedoras de renombre (esto será ampliado más adelante).

\section{La cuestión de la nacionalidad}

Este es un tema debatido y recurrente en muchos comentaristas tanto antiguos como modernos. La mayoría de ellos se inclinan a pensar que eran hebreas (p. ej., Andiñach, Childs, Exum) porque resulta difícil concebir que mujeres egipcias asistieran los partos de las esclavas. Pero no todos coinciden con ello. Desde un punto de vista lingüístico, la cuestión que no encuentra una clara solución: "Si bien la puntuación masorética es inequívoca, el texto consonántico permite entender la palabra hebreas en este versículo tanto como que son las parteras que asisten a las hebreas (en ese caso podrían ser parteras egipcias) como que son ellas mismas hebreas de nacionalidad" (Andiñach, 2006, p. 35).

Por su parte, tanto la Septuaginta como la Vulgata traducen la expresión העבית מילדת como un

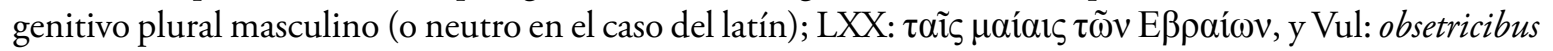
Hebraeorum. Esta opción por el genitivo lleva a pensar si los traductores fueron influenciados por una lectura distinta de la que luego harían los masoretas o si prefirieron dejar abierta la interpretación de la nacionalidad de las parteras.

6 Los ladrillos de nacimiento egipcios (Roth y Roehrig, 2002, pp. 129-139) y los partos en el antiguo Egipto (Töpfer, 2014, pp. 317-335).

7 Características de las comadronas en la Sagrada Escritura (García, 1999, pp. 14-15), el significado del término tAYërIb. [i en Ex 1,16 (McGeough, 2006, pp. 305-318; Morschauser, 2003, pp. 731-733).

8 Técnicas antiguas reflejadas en la Biblia (Barnawi et al., 2013, pp.115-116) y la silla de parto en Egipto (Lattus y Carreño, 2010, pp. 45-47). 
Desde un punto de vista sociológico, por la delicadeza y confianza que implica un parto, resulta difícil pensar que un conjunto humano, los hebreos, que en este estadio se movían según el clan, admitieran extranjeras para una tarea tan íntima. Además, ellas y el pueblo serán beneficiarios de la bendición de Dios (vv. 20-21), lo cual parece más lógico en mujeres hebreas que en egipcias (Childs, 2000, p. 56).

Se abre una posible objeción: resulta difícil suponer que el faraón confiara la tarea de matar a los recién nacidos hebreos a mujeres hebreas. En esta línea, Flavio Josefo (1961) escribe: "Dispuso [el rey], además, que las parteras egipcias vigilaran a las mujeres hebreas y observaran a los recién nacidos, porque quería que cumplieran esas funciones con las mujeres hebreas las parteras que, por ser compatriotas del rey, no infringirían sus órdenes" (lib. II, cap. IX, p. 152). En la misma línea, algunas leyendas hebreas se distancian de la tradición y sostienen que las parteras eran egipcias que llevaban a cabo las órdenes del faraón (Ginzberg, 1980, p 257). De modo similar, Römer (2015) afirma que "a la luz de la lógica narrativa la identificación de las parteras como egipcias es ciertamente obvio" (p. 241).

Por su parte, Janssen (2018) presenta una explicación que congeniaría la nacionalidad hebrea con sus conocimientos obstétricos y la confianza del faraón. Para la autora, en atención a la gran cantidad de mujeres que formarían parte del harén del monarca y los constantes embarazos y partos que resultarían, se puede pensar que Sifrá y Puá eran las parteras (o las jefas de las parteras) de las esposas y concubinas del rey. Esto explicaría la ambigüedad lingüística: "parteras para” y "parteras de" las hebreas (pp. 14-16).

Ahora bien, desde la perspectiva del actuar de Dios, esta cuestión de la nacionalidad (hebreas, egipcias o, incluso, otra) se vuelve decisiva a la hora de interpretar su accionar, como expone Langston (2006):

Su origen étnico marca una diferencia en el relato. Como egipcias, ellas son un ejemplo de la habilidad de Dios de usar no hebreas para lograr sus objetivos y pese a ser extranjeras las hace merecedoras de su bendición. Como hebreas, ellas se vuelven símbolo de la lucha nacional por la libertad. (p. 18)

Otro elemento es la respuesta de las comadronas al faraón: "Las hebreas no son como las mujeres egipcias, ellas son vigorosas" (v. 19). Al referirse a las hijas de Jacob en tercera persona plural, surge una cuestión, si el uso de "ellas" responde a que las parteras no son hebreas (sino podrían haber dicho: "nosotras, las hebreas") o lo hacen de modo impersonal, no incluyéndose, para evitar decirle en la cara al rey que las mujeres del pueblo oprimido son más fuertes que las del opresor.

Ambas respuestas, según la nacionalidad, están cargadas de ironía, ya que, si las comadronas no son hebreas, están reconociendo que estas últimas son más fuertes que ellas; si fuesen hebreas, las comadronas reconocerían ante el faraón, de modo indirecto, que también son mujeres vigorosas.

Desde la perspectiva de los nombres de las parteras, los mismos no aparecen en ningún otro lugar de la Escritura, lo cual tampoco permite deducir si estas eran hebreas, egipcias o de otra nacionalidad. Para Exum (1983): "Los nombres Sifrá y Puá son semíticos, pero este hecho no constituye un argumento concluyente [en lo referente a su nacionalidad]" (p. 72). Por su parte De Vaux (1974) sostiene:

Los nombres de estas son interesantes; son semíticos de un tipo antiguo: Siprá se encuentra en una lista de esclavos asiáticos en Egipto, en el siglo XVIII a. C. [W. F. Albright: JAOS 74 (1954) 222-233, cf. 
Sifrá y Puá: valientes, rebeldes y sabías heroínas. La figura y el accionar de las parteras en Ex 1, 15-22

229.]; Púa es, en los poemas de Ras Samra, el nombre de una de las hijas de Daniel, pgt, que también en ugarítico es un nombre común que significa "chica joven" [C. H. Gordon, Ugarit Textbook (Rome 1965) Glosario, n. 2081; J. Aistleitner, Wörterbuch der ugaritischen Sprache (Berlín² 1965) n. 2246]. (p. 318)

Como se verá más adelante, la literatura rabínica desarrollará el significado de sus nombres. Finalmente y como conclusión a esta cuestión, después de lo analizado no nos decidimos por una postura unívoca (hebreas, egipcias u otras). Para nosotros, el tema queda en suspenso. El autor ha construido un relato enigmático y abierto; el texto no tiene intención de mostrar su nacionalidad, "sino primero en su toma de posición por los niños a pesar de los riesgos, y segundo, su decisión de evadir al faraón por medio de la excusa (¿o mentira?)” (García, 1999, p. 14). La única nacionalidad importante en el relato es la de las destinatarias del accionar de las parteras: las hebreas.

\section{Los nombres del relato}

En cuanto a sus nombres, no se debe perder de vista la importancia de su mención en el texto en contraposición al rey de Egipto, quien es anónimo. La posesión del nombre indica que ellas son alguien relevante con una misión:

El nombre dado en el nacimiento expresa ordinariamente la actividad o el destino del que lo lleva [...] puede evocar las circunstancias del nacimiento o el porvenir entrevisto por los padres [...] a veces es una especie de oráculo [...] En todo caso el nombre dice el potencial social de un hombre hasta el punto de que "nombre" puede significar también "renombre" (Núm 16, 2), y estar sin nombre es ser un hombre sin valor (Job 30, 8). (Leon-Dufour, 1990, p. 590)

Asimismo, "no es de despreciar, considerando la frecuencia con que las mujeres son anónimas en la Biblia” (García, 1999, p. 13). Por el contrario, el anonimato del faraón responde a una apreciación del monarca como alguien sin valor.

Por su parte, Siebert-Hommes (2010) relaciona los nombres de los personajes con sus acciones en el relato: las parteras "se aseguran de que los niños vivan. El rey, por el contrario, manda matarlos, aunque se muestra impotente: lo que él hace no puede tener un nombre. Las parteras, por el contrario, se han hecho un nombre mediante sus actos" (p. 309).

No se debe pasar por alto que el texto está ubicado en el libro que comienza con la expresión שִ̣iו אֶלֶה ("Estos son los nombres"), y que en la tradición judía se denomina así o simplemente שֶׁוֹ, lo cual revela una gran ironía. En un libro en que el nombre de los patriarcas se perpetúa en una muchedumbre (Ex 1,7), el gran profeta de Israel recibe su nombre $(\operatorname{Ex} 2,10)$ y Dios revela el suyo $(\operatorname{Ex} 3,14)$, que las parteras tengan nombre y no así el rey de Egipto pone de manifiesto su importancia.

La literatura rabínica, or su parte, unió los nombres de las parteras con Yoquébed y Miriam, la madre

y hermana de Moisés, quienes se ingeniaron para salvarlo, como también se relacionó los nombres con sus acciones por medio de diversas etimologías. 
En el Tárgum Neofiti se dice: "Y porque las parteras temieron delante de Yhwh, se granjearon un buen nombre [...] Miriam tomó la corona del reino y Yokébed tomó la corona del sumo sacerdocio" (Martínez y Pérez, 2011, p. 6). En Éxodo Rabbah 1, 13 (1, 15 en el texto canónico):

¿Por qué se llama Yokebed Sifrá? Porque era la que limpiaba (mšprt) al bebé. ¿Y a Miriam Puá? Porque soplaba $(n p$ ' $t$ ) vino tras la acción de su madre. Otra opinión: Sifrá, porque los israelitas crecieron $(p r w)$ y se multiplicaron por su medio; Puá, porque insuflaba (mpy ' $h$ ) al bebé cuando se decía que estaba muerto. Otra opinión; Sifrá, porque cuidaba (šprh) sus acciones ante Dios; Puá, porque presentó $(h w p y$ `h) a Israel ante Dios. Otra opinión: Puá, porque hizo frente $(h w p y$ ' $h)$ al faraón y se mostró insolente con él [...] Sifrá, porque suavizó (mšprt) las palabras de su hija y tranquilizó (a Faraón). (Girón, 1989, pp. 37-38)

Y en el Talmud se lee:

¿Por qué le decían Shifrá? Porque embellecía (meshaperet) al niño. Otra explicación: [Le decían] Shifrá porque en su tiempo los israelitas fructificaban (sheparu) y se multiplicaban. Puá es Miriam. ¿Por qué le decían Puá? Porque gritaba ( $p e a ́)$ para hacer salir a la criatura. Otra explicación: [Le decían] Puá porque por medio del Espíritu Santo gritaba y decía: Mi madre engendrará un hijo que salvará a Israel. (Calés, 2004, p. 48)

La mención de sus nombres señala que ellas son seres reales, concretos, que ofician un rol significativo y decisivo para la supervivencia del pueblo hebreo.

\section{El temor de Dios}

Las parteras, por su parte, no cumplen el mandato del faraón y dejan con vida a los niños. La causa: "tenían temor de Dios”. El verbo רא posee como primer significado temer, asustarse, acobardarse, etc. Pero, unido a alguno de los términos utilizados para referirse a Dios, adopta un sentido propio proveniente del campo religioso: dar culto, respetar a Dios, adorarlo, serle fiel, etc. (Alonso, 1994, pp. 332-334).

Si bien este concepto aparece solo dos veces en el texto (vv. 17.21), en ambos la estructura es semejante, tienen el mismo sujeto: las parteras. El relato enfatiza que son solo ellas quienes poseen esta actitud religiosa.

El temor de Dios las lleva a venerarlo y defender la vida, y así muestran que aquel no es solo una actitud cultual, sino activa, es decir, ligada o proyectada en otros, por así decir, que abraza la vida y la defiende, incluso a costa de ellas mismas, desobedeciendo al todopoderoso faraón, a quien no le tienen miedo. Tras esto se convierten en un modelo de santidad de la desobediencia y resistencia a órdenes de la muerte (Porcile, 2008, pp. 18-20).

El temor de Dios se transforma en un elemento clave en el relato. Primero, evita la matanza de los varones recién nacidos, así la muerte no pone en peligro la vida. Segundo, es causa de beneficios para el pueblo y las mismas parteras. Es una verdadera causa eficiente vital: da, defiende, protege y crea vida. 


\section{Mujeres sabias}

El temor de Dios hace de ellas mujeres sabias, puesto que para el pensamiento israelita esta actitud religiosa es causa de sabiduría ( $\operatorname{Pr} 9,10 ; 31,30 ;$ Sal 111, 10). Sus convicciones y su piedad las presentan como modelos para el pueblo de Israel. Por ello, sostiene Childs (2000): "La piedad de las comadronas refleja el ideal religioso de los círculos sapienciales. Su negativa a obedecer al Faraón procede de un 'temor de Dios'. Esta piedad se refleja en la sagacidad y en la capacidad para hacer frente a la acusación del Faraón con argumentos racionales" (p. 53).

Por su parte, en Éxodo Rabba 1, 15 (Ex 1, 17 en el texto canónico), también se desarrolla este aspecto, primero relacionándolo con el texto de Pr 31, 30: "Mas las parteras temieron a Elohim. De ellas se dice: 'La mujer que teme a YHWH, esa ha de ser loada"' (Girón, 1989, p. 39), y luego asociándolo a la conducta de los antepasados:

Otra explicación (sobre) "más las parteras temieron a Elohim" indica que adecuaron sus hechos a los de sus antepasados, es decir, Abraham, nuestro padre, que se instaló una posada y daba de comer a los viandantes, que eran incircuncisos; mas nosotras, por si no fuera bastante que no tengamos con qué alimentarnos, por el contrario hemos de matarlos. (Girón, 1989, p. 40)

En ambos casos, hay un elogio al temor de Dios de las parteras, cuya conducta es asociada a la de Abraham, patriarca del pueblo.

La personificación femenina de la Sabiduría es un tema clásico de la literatura cristiana, la cual ha cobrado gran interés en la teología feminista. Johnson (2009) expone que las mujeres que luchan contra la injusticia dan un "espléndido y sorprendente testimonio femenino" que ofrece nuevas imágenes para hablar del Sophia-Dios que no es indiferente del sufrimiento. Así, se refiere al obrar de las parteras:

En este relato del Éxodo, la Sabiduría contó para su propósito con la colaboración de mujeres de diferentes clases, razas y edades: con la astuta y desafiante intervención de las comadronas Sifrá y Fuá, que se negaron a acabar con nuevas vidas; con la madre de Moisés y su hermana Miriam, que ocultaron y alimentaron al nińo; y con la hija del faraón, que lo protegió (Ex 1-2). Sabiduría hace ahora que Moisés tenga consciencia de su misión profética y alienta su valor. En cada generación, las mujeres que trabajan y sufren por la justicia, haciendo frente a la indiferencia o la rabia de los poderosos, son cooperadoras de la ardiente llama de Sabiduría, sacramentos de su voluntad de liberación. Sus vidas sirven de metáfora del doloroso compromiso de Dios, que ama la justicia. (pp. 326-327)

Ante la muerte, el temor de Dios se vuelve astucia, ${ }^{9}$ ingenio y habilitad para enfrentar la situación. ${ }^{10}$ No proponen una razón fútil y baladí. Igualmente, la astucia se convierte en deliberada desobediencia

9 "Las comadronas de Ex 1 y la nodriza o ama de cría (mêneqet) de Ex 2 aparecen como resistentes a la opresión y al genocidio decretados por el faraón. Su astucia salva al pueblo de Israel y permite continuar los planes de Yahvé" (De León Azcárate, 2011, p. 73).

10 "Esta piedad se muestra a sí misma en el ingenio y habilitad para hacer frente a la acusación del faraón con argumentos racionales" (Childs, 1965, p. 120). 
ante la opresión y la matanza, incluso arrojo. Ellas preservan la vida, aun poniendo en peligro la propia. Esta actitud sapiencial es causa de reclamo y queja para el malvado; pero a los ojos de Dios se volverá un beneficio para los que hacen el bien y para todo el pueblo.

\section{El accionar de las parteras}

En el versículo 17, el accionar de las parteras se expresa con dos verbos: שיה y עשה. El primero en sentido negativo, "no hicieron", rige una subordinada que remite a la orden del rey. En cuanto al verbo nיה piel, posee el sentido no solo de dejar con vida, sino también de respetar la vida y dar vida; en un sentido amplio, incluso, significa criar, alimentar, hacer revivir, etc. (Alonso, 1994, pp. 243-245). Así, se refleja de modo más profundo el obrar de las comadronas, quienes son mujeres de la vida en todos sus aspectos. Ellas abrazan la vida, como se abraza al recién nacido, y poseen "ojos que ven y saben preservar la vida, conservarla y dejarla crecer" (Porcile, 2008, p. 77).

En el versículo 18, el rey de Egipto les pregunta por su accionar, el cual es una clara desobediencia a sus órdenes. Un soberano todopoderoso interroga a unas simples parteras, que mostrarán astucia y que terminarán teniendo el control de la situación.

\section{Mediación y Providencia}

El temor de Dios es presentado como una actitud religiosa activa en el relato. No es una virtud que solo reside en aquellos que lo practican, sino que es una virtud transitiva. Un bien que influye en la vida de otros. Se emparenta con la virtud de la prudencia: hacer lo adecuado en el momento adecuado.

Dios enfrenta al faraón y salva al pueblo a través de las parteras: "La primera acción de Dios no es a través del macho (Moisés), sino por medio de la hembra, las mujeres en Egipto y su sentido maternal. Es el primer obstáculo que intenta vencer el poderoso Faraón: la vida del niño es protegida por la mujer/ madre" (Henao, 2011, p. 387).

Un elemento asociado a la mediación que solo aparece en las leyendas hebreas es la piedad de las parteras, quienes elevan sus súplicas a Dios pidiendo por ellas mismas, ya que desobedecen al faraón, y por los niños, para que nazcan sanos y salvos. Incluso, se narra que Dios escuchó sus oraciones, y no solo les concedió esto, sino que aun, mientras Sifrá y Puá sirvieron como parteras, ningún niño nació paralítico, ciego o con otra discapacidad (Ginzberg, 1980, p. 253). Así, los frutos de su oración son sobreabundantes.

Ellas no solo son mediadoras de la Providencia en favor del pueblo, sino que ellas mismas se hacen Providencia, son las manos maternales del Dios que cuida y protege a su pueblo. 


\section{Un ejemplo de desobediencia civil}

El accionar de las parteras también puede ser visto desde un punto de vista jurídico, ya que en la Antigüedad las órdenes de un rey revestían validez jurídica y se transformaban en leyes. Su incumplimiento era considerado una transgresión legal. En ellas, "el libro del Éxodo comienza presentándonos un precioso acto de resistencia” (Barroso, 2006, p. 198).

El Diccionario de la lengua española (Real Academia Española [RAE], 2014) define la desobediencia civil como "resistencia pacífica a las exigencias o mandatos del poder establecido". Pese a ser un concepto moderno, puede ser aplicado a la desobediencia de las parteras.

En el comienzo de la historia [del Éxodo] y asociado al cumplimiento de la promesa de multiplicarse, encontramos que las parteras son presentadas como modelos de fe a seguir en su desobediencia civil. Su rechazo a implementar la política genocida es motivado por su elección de temer a Dios antes que al faraón. (Sheriffs, 1990, p. 53)

Otros conceptos legales emparentados son la obediencia ciega ${ }^{11}$ y la obediencia debida. ${ }^{12}$ Ellas optaron no seguir las órdenes del faraón, no les importó la autoridad terrenal que envestía. El dictado de su consciencia estaba por encima de las órdenes del monarca:

Al hacer esta elección, pusieron en peligro su propia vida. Su ejemplo es un desafío para los que justifican su comportamiento antiético diciendo: "Solo estaba siguiendo las órdenes de mi jefe". Dios no acepta esta justificación. Él exige que le obedezcamos, no obstante los riesgos. Si los africanos estuvieran dispuestos a asumir esa misma postura, probablemente habríamos sido ahorrados de muchos asesinatos políticos y otras muertes, de varios desvíos de fondos públicos y otras prácticas perjudicantes. (Ndjerareou, 2010, p. 89)

Sus convicciones religiosas, es decir, su temor de Dios, las llevó a desobedecer, a no seguir las órdenes asesinas y, por tanto, a transgredir la autoridad del rey de Egipto.

En esta misma línea jurídica, Ska (2006) explica la diferencia entre el derecho y las leyes. El primero es inmutable y no depende del hombre, mientras que las leyes tienen una validez limitada en un espacio, tiempo y grupo concreto. Para ilustrar esto, pone varios ejemplos bíblicos, siendo el primero la desobediencia de las parteras quienes "reconocen una autoridad superior a la del faraón; en concreto, con su comportamiento afirman que el faraón no tiene autoridad sobre la vida y la muerte de los neonatos” (p. 471).

Y, finalmente, no se puede soslayar que su accionar se emparenta con un tema de gran actualidad: la objeción de consciencia ante leyes y prácticas médicas abortistas. En reiteras ocasiones, parteras y obstetras, son profesionales de la salud que se enfrentan en muchos países a sistemas, que consideramos perversos, que no tienen piedad ante la vida por nacer. Decisiones estatales avaladas por ley que las obliga a llevar a cabo abortos en nombre de la libertad, el derecho a elegir o, incluso, por razones médicas.

11 "Obediencia que se presta sin examinar los motivos o razones de quien manda".

12 "Obediencia que se rinde al superior jerárquico y es circunstancia eximente de responsabilidad en los delitos". 
No es la intención de este estudio adentrarse en cuestiones que atañen a la moral. Solo se desea poner de relieve la existencia de muchos profesionales de la salud que defienden el don de la vida, al igual que las parteras, con valentía e ingenio persuadiendo y aconsejando sabiamente, incluso a costa de poner en juego sus profesiones.

\section{La respuesta de las parteras: valentía, vida e ironía}

Ante el reclamo del faraón, las parteras, hábilmente, se excusan: las hebreas no son como las egipcias. Aquellas son vigorosas, no ¡más vigorosas! A secas: vigorosas. No es redundante decirlo: las egipcias no son menos. Sencillamente son débiles.

El diálogo entre el rey y las parteras (vv. 18-19) es claramente irónico. Incluso, es el clímax de la ironía del relato. Dos simples comadronas, con total seriedad y sin titubear, mienten y se burlan en la cara de un soberano terrenal, e inventan un argumento en el cual las mujeres oprimidas son más fuertes que las mujeres del pueblo opresor.

El texto contrapone a las hebreas con las egipcias. No son iguales; unas son fuertes, las otras débiles, o, mejor dicho, no son como las hebreas: son carentes de vigor. El adjetivo utilizado para referirse a las

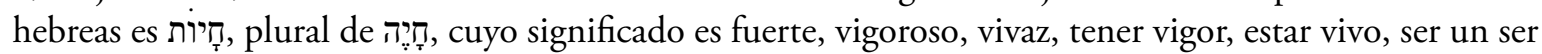
vivo, conservar la vida, etc.; como también bestia, animal (salvaje), fiera, etc. (Alonso, 1994, pp. 243-245).

La relación entre ser vigoroso y tener vida es obvia, y en hebreo esta relación lo es mucho más por provenir de una misma raíz. Esto no ocurre en castellano, en que el énfasis está en la fuerza o actividad que se manifiesta en el vigor. En hebreo, el énfasis está más bien en la vitalidad. Esta, ciertamente, no se contrapone a la idea de fuerza, pero conviene poner de relieve cómo el texto insiste, de un modo o de otro, en el hilo dorado de la vida.

Decir que son vigorosas, fuertes y robustas significa que las hebreas son vitales, que tienen vida. Tienen una vitalidad fuerte, vigorosa. Las egipcias, por el contrario, una vitalidad endeble, débil. A un rey que ordena quitar la vida las comadronas le anotician que las hebreas poseen y dan vida.

Por otra parte, cabe notar que el texto parece jugar también con el sentido animal o salvaje del término. Y así las hebreas son como los animales salvajes: fuertes y no necesitan ayuda de una partera para dar a luz. Como ellos, dan a luz por sí solas. ${ }^{13}$ Este matiz o asociación que podría chocar con la sensibilidad actual posee una carga de gran ironía: las parteras le dicen al monarca que las mujeres hebreas son como animales,

13 Llama la atención que LXX omite la calificación de las hebreas. Posiblemente para la mentalidad helenista era ofensivo comparar a las mujeres con animales, por lo cual se prefirió no incluir el sustantivo. Por su parte, la Vulgata en lugar de la adjetivación trae la siguiente frase: "ipsae enim obsetricandi habent scientiam" (ellas, pues, tienen conocimiento del oficio de la comadrona). Esta tradición diferente nos lleva a pensar si esta no depende de un texto hebreo distinto masorético o de una interpretación judía que influyó en san Jerónimo. Finalmente, debemos señalar que la Nova Vulgata, en ese versículo traduce: “ipsae enim robustae sunt”, y así sigue el texto masorético y no el texto de la Vulgata. 
para quien es reconocer que las oprimidas son inferiores; pero, para las parteras, es decirle en su propia cara que las mujeres oprimidas son más fuertes. El matiz de animalidad es desarrollado en la literatura rabínica y en las leyendas hebreas (Ginzberg, 1980, p. 253). En Éxodo Rabbah 1, 16 (1, 19 en el texto canónico), como el Talmud (Sota 11b), se compara a las mujeres hebreas con animales y se enumeraran algunas citas de la Escritura en que el pueblo es comparado con animales:

Y las parteras respondieron al faraón: Porque las mujeres (hebreas son vivaces), etcétera. ¿Qué significa jaiot? ¿Diremos que significa literalmente parteras? ¿Es que una partera no necesita partera para dar a luz? Será más bien que le dijeron: En esta nación se usa la comparación de la fiera (jaia): Judá es cachorro de león. (Calés, 2004, p. 48).

\section{Dos heroínas bíblicas}

Es importante señalar que las parteras que enfrentan al faraón, un monarca todopoderoso divinizado por su pueblo; no son dos mujeres con estudios médicos universitarios o dos heroínas de una "película de Hollywood" (jóvenes, con hermosos trajes y cuerpos despampanantes), sino dos mujeres mayores, "comadronas de pueblo", que, incluso, pudieron ser esclavas.

La desproporción entre ellas y el monarca es inmensa, pero esto no las acobarda; por el contrario, presentan batalla en lo oculto, en lo doméstico, en la esfera propia que su cultura y su tarea les asignaba. El faraón quiso entrometerse donde ellas ejercían su oficio en pos de la vida y fue vencido.

Sifrá y Puá se convierten en mujeres que rompen los estereotipos culturales de su época y llevan adelante acciones extraordinarias, salvíficas y transgresoras. Ellas no son dos damiselas débiles que necesitan de un heroico galán o un príncipe azul que las salve, como en un cuento clásico, sino todo lo contrario: dos mujeres maduras que, con coraje y astucia, salvan a los varones recién nacidos y al pueblo. Ellas son heroínas bíblicas como Débora, Jael, Judit y Ester; mujeres valientes, amantes de su pueblo y fieles a Dios.

\section{Bonum est diffusivum sui}

El obrar de las parteras, sin saberlo, conlleva su recompensa. Dios les hace el bien, y este parece ser extensivo al pueblo, que se beneficia con un gran crecimiento. El versículo 20 está compuesto por dos oraciones. La primera hace referencia al premio que reciben nuestras heroínas: "Y Dios hizo el bien a las parteras"; la segunda, al bien con que se benefició a los hijos de Israel: "se multiplicó el pueblo y se hicieron fuertes de modo exuberante".

Pero ¿en qué consiste este bien que reciben las parteras de Dios? El narrador lo deja en suspenso, luego lo clarificará. Lo primero que surge es la pregunta: ¿por qué el relator habla primero de la multiplicación del pueblo, de su crecimiento exuberante (v. 20bc) y luego de la descendencia de las parteras (v. 21)? Probablemente, el autor quiera mostrar al lector que los beneficios del pueblo quedan enmarcados en los 
de las parteras, es decir, poniendo de manifiesto que el pueblo se beneficia a través de estas. Sin duda, el foco de atención es el pueblo, pero por mediación de las comadronas. Obsérvense los versículos 20-21:

\begin{tabular}{|l|l|}
\hline Beneficio indefinido de Dios a las parteras & 20 "Y Dios hizo el bien a las parteras". \\
\hline Beneficios específicos al pueblo de Dios & $\begin{array}{l}\text { "Y se multiplicó el pueblo y se hicieron fuertes de modo } \\
\text { exuberante". }\end{array}$ \\
\hline Beneficio específico de Dios a las parteras & $\begin{array}{l}21 \text { "Y porque las parteras tuvieron temor de Dios, les dio } \\
\text { descendencia". }\end{array}$ \\
\hline
\end{tabular}

No solo esta estructura sino también en los sujetos de los verbos de los versículos 20-21 se pone de manifiesto la relación parteras-pueblo. Aquellas son beneficiadas directamente por Dios, quien les "hizo el bien" y "les dio descendencia". En el centro de la estructura recién propuesta, el pueblo "se multiplicó" y sus miembros "se hicieron fuertes" como teniendo una fuerza interna que los hace resurgir y expandirse. Pero esa fuerza está suscitada por el accionar de las parteras. Ellas hacen que esa fuerza fructifique.

El bien que Dios hace a las parteras no se debe perder de vista, sino que está en consonancia con su accionar y convicciones: ellas defendieron la vida, por tanto, Dios las premia con vida, muchas más vida.

\section{La descendencia de las parteras}

Finalmente, el narrador, maestro del suspenso, en el versículo 21, informa al lector cuál fue el bien que Dios hizo a las parteras: el favor de Dios, su premiación. El autor precisa que la razón del beneficio divino es el temor reverencial hacia Él y esto les proporciona descendencia.

El versículo 21 no presenta novedades en cuanto al léxico. Este corresponde, en buena medida, con el del versículo 17. Al comparar ambos versículos de modo paralelo, se puede afirmar que el actuar de Dios con las parteras es especular al actuar de estas en relación con la orden del faraón.

En el análisis del versículo anterior, se hizo referencia, por una parte, a que el narrador no nos dice cuál es el "bien" que las parteras reciben; por otra, no se afirma explícitamente qué o quién es la causa agente de ese "multiplicarse y hacerse fuertes de modo exuberante". El lector lo intuye, pero parece preferir, en ese lugar, ligar "parteras/pueblo". Aquí, en cambio, el agente es el mismo Dios. El pueblo crece y a las parteras les da descendencia. Literalmente, Dios "les hace casas".

El verbo עשה aparece tres veces en la perícopa (vv. 17, 18, 21), aplicado, primero, a las parteras quienes "no hicieron" lo que quería el rey; en segundo lugar, en boca del faraón, quien constata la desobediencia de aquellas (“¿Por qué obraron así?”). Y, por último, aplicado a Dios quien les “hizo” la descendencia. Junto 
al juego narrativo que se percibe en relación con el verbo, ${ }^{14}$ el relato no deja de tener un halo creacional que remite a Gn 1. El pueblo, en vías de extinción, es recreado. Ante las tinieblas con las que el faraón cubre la descendencia de Abraham, Isaac, Jacob, el soberano del cielo hace luz.

Y junto con esta relación genesíaca, creacional, se cumple el principio rabínico que reza: "Con la misma medida con que midiereis seréis medidos", ${ }^{15}$ pues, al defender la vida, recibieron vida; al proteger la descendencia, fueron premiadas con descendencia.

La última palabra que cierra la narración sobre las parteras es justamente por descendencia, casas o familias. El relato no dará más referencias sobre ellas, pero queda sobrevolando la idea de que ellas, las cuidadoras de la vida, tuvieron casas, familia y descendencia.

Desde una lectura simbólica, el autor puede estar pensando que a las parteras, quienes han sido un refugio de la vida en peligro, se les concede una descendencia coherente. Desde ellas se prolonga el cuidado, la protección que caracteriza o debiera caracterizar a la familia, a la descendencia. En ellas, no se da solo una prolongación de la estirpe, sin que se perpetúa lo que las ha caracterizado en el relato. Su fuerza, convicción, fidelidad y arrojo. Las parteras, a quienes no se vuelve a mencionar en la Escritura, quedan perpetuadas hacia el futuro. Eso es lo que el texto parece querer decir.

Esta misma línea, algunas obras rabínicas asocian la descendencia o las casas que Dios hizo a las parteras con las casas reales, levíticas y sacerdotales de Israel. En el Tárgum Neofiti: "les hizo casas, la casa del reino y la casa del sumo sacerdocio. Miriam tomó la corona del reino y Yokébed tomó la corona del sumo sacerdocio" (Martínez y Pérez, 2011, p. 6). En el Tárgum Pseudo Jonatan: "la Palabra de Yhwh edificó para ellas la casa del reino y la casa del sumo sacerdocio" (Martínez y Pérez, 2011, p. 6). Por su parte, dice el Talmud:

Y sucedió que por haber temido las parteras a Dios, él les hizo casas. [Sobre esto disienten] Rab y Shemuel. Uno dice que eran casas sacerdotales y levíticas; el otro dice que eran casas reales. Uno dice que eran casas sacerdotales y levíticas: Aarón y Moisés. El otro dice que eran casas reales, porque también David descendía de Miriam, como dice lo escrito: Muerta Azaba, tomó Caleb por mujer a Efrata, la cual dio a luz a Hur. Y dice: Y David era hijo de aquel hombre efrateo, etcétera. (Calés, 2004, p. 48)

Sin adentrarse en el tema, podría pensarse que esta asociación con las principales casas de Israel es un uso político del renombre de las parteras, y así se arrogaron descender de estas. Más allá de esta posible manipulación, el recurso de pertenecer a su descendencia pone de manifiesto la densidad simbólica de estas como heroínas populares.

14 El no hacer-hacer de las parteras, el querer-hacer/no hacer del faraón, el hacer de Dios. No asesinar-custodiar la vida, querer el exterminio de los varones/frustración por manos de otro, hacer la fecundidad.

15 "Partiendo del principio de unidad de la Escritura de la exégesis midrásica, una analogía privilegiada es la analogía ética: los exegetas destacan la correspondencia entre conducta y retribución: Middá k冈-néged midda”" (Del Agua Pérez, 1985, p. 51). 


\section{Maternidad y filiación}

Los términos y las raíces hebreas presentes en el texto permiten apreciar la importancia que tienen los conceptos vida, nacimiento y descendencia, todos emparentados con la paternidad, maternidad y filiación.

En cuanto a las parteras, son las madres del pueblo en el relato. Inteligentes, sagaces y astutas. No solo por los conocimientos de su oficio, sino por ser causa de la multiplicación del pueblo y ser ellas mismas bendecidas con descendencia.

Como ya se señaló, muy probablemente las parteras eran mujeres posmenopáusicas, por lo cual podemos considerarlas parte del grupo de matriarcas estériles (Sara, Rebeca, Raquel, Ana e Isabel) que dan vida por obra de Dios (en este caso por su temor de Dios) y no por su capacidad fisiológica.

Por ello, la literatura rabínica les atribuyó ser las engendradoras de las principales casas de Israel. Y las leyendas hebreas relatan que ellas no solo dejan con vida a los nińos, sino que se ocupaban de estos proveyéndoles alimento y aquello que necesitaran, es decir, protegiendo la vida de un modo íntegro, como madres que no solo dan la vida, sino que nutren, protegen y cuidan (Ginzberg, 1980, pp. 252-253).

El pueblo, también conocido como "hijos de Israel”, aparece como un hijo que nace y crece por la acción conjunta del Dios fiel y las parteras/madres temerosas de Dios. Conjunción de voluntades en sintonía.

\section{Solidaridad femenina, sororidad y resistencia}

El texto presenta un clarísimo modelo de solidaridad femenina y resistencia ante la opresión. Un canto a la esperanza, pues los débiles vencen a los poderosos. La lucha se desarrolla durante el trabajo de parto, un momento netamente femenino. ${ }^{16}$ Se teje una complicidad salvadora entre mujeres: la parturienta, las comadronas (sean hebreas o egipcias ${ }^{17}$ ) y otras mujeres, familiares, amigas o vecinas. Una complicidad fruto de la compasión, de la defensa de la vida, su temor de Dios, de su ser mujeres dadoras de vida.

En el silencio, en un ambiente doméstico y oculto, donde solo entraban las mujeres, se resiste y se lucha contra el faraón. No con armas o estrategias militares, sino con el oficio de parteras.

La complicidad solidaria de las mujeres es un acto valiente de piedad salvadora que, saltando por encima de las diferencias, de las leyes injustas, y arrostrando las dificultades, las amenazas y prohibiciones, posibilita la vida y abre la puerta de la historia de la gran liberación del pueblo judío, que reconocemos con el nombre de Éxodo. Estas mujeres posibilitaron el futuro, porque, sin este acto, el pueblo judío hubiera sido totalmente suprimido y nunca se hubiera cantado ese gran himno salvífico y liberador por excelencia que

16 La presencia de hombres en el momento de alumbramiento es bastante reciente, durante siglos y hoy en muchas culturas solo participan las mujeres.

17 Si fueron las parteras egipcias, significa que fueron capaces de tender puentes y derribar fronteras étnicas, religiosas y sociales (opresores y oprimidos), para salvar la vida junto con otras mujeres. 
es el libro del Éxodo; en realidad todo él es la expresión de la "resistencia" del Pueblo y del apoyo liberador de Dios; ahí, en este apoyo, leyó y percibió Israel con toda claridad, la acción poderosa y amorosa de Dios liberando a su Pueblo y lo comunicó generación tras generación. (Arana, 2006, p. 99)

Mientras el rey buscaba la muerte, ellas protegían la vida. Su rechazo a "obedecer las órdenes del rey y su resistencia es el comienzo de la liberación” (Pixley, 2010, p. 49), que narra el Éxodo. El tirano fue vencido por dos simples comadronas del pueblo en un duelo excepcional en que se enfrentaron: poder versus debilidad, muerte versus vida, opresor versus oprimidas. ${ }^{18}$ Las mujeres que ayudaban a dar a luz se convierten en luz ante las tinieblas.

\section{Conclusiones}

Ex 1, 15-22 pone de bruces al lector ante la lucha entre el poder de la vida y el poder de la muerte. Lucha llevada a cabo, en este caso, por dos simples pero valientes y sagaces comadronas. Ellas no titubean ni flaquean ante el poder del faraón. Por el contrario, por su temor de Dios, defienden la vida, que se transforma en un canto de esperanza ante situaciones en que la muerte pareciera tener la última palabra.

El relato es una gran lección de humanidad, de lucha contra la opresión, de defensa de la vida, de cuidado del débil. Pero también es texto religioso que enseña acerca del valor del temor a Dios, la fe puesta en acción, la Divina Providencia y la fidelidad de Dios a su promesa.

El texto presenta una imagen muy atrayente y rica de la mujer y su accionar a favor de los más débiles y desprotegidos, por lo que se comprende por qué ha tenido mayor una recepción y desarrollo en la exégesis y la teología feminista. Desde esta perspectiva, se puede señalar que el relato centra su atención en el accionar de dos mujeres, quienes dan vida en doble sentido: por profesión y por desafiar al faraón. Por esa razón, sus nombres son recordados (Exum, 1983, pp. 70-75). La posesión de nombres indica su importancia en el relato, "considerando la frecuencia con que las mujeres son anónimas en la Biblia" (García, 1999, p. 13), afirmación algo discutible, por otra parte.

Su oficio las convertía en una ayuda necesaria para las mujeres en el parto, como en el cuidado de la creatura y la madre. Por otra parte, poseen el poder de decidir sobre la vida y la muerte (García, 1999, pp. 14-15). Ellas, como las mujeres que salvan a Moisés (Ex 2, 1-10), toman una decisión: enfrentarse al faraón y "todas ellas eligen la vida, y no la muerte" (Exum, 1983, p. 81).

Las parteras, en su enfrentamiento con el faraón, marcan el tono de la narración bíblica: la confrontación entre poderosos y débiles (Weems, 1992, p. 32). Su rol es fundamental en la liberación

18 La solidaridad entre mujeres continuará en el relato del nacimiento de Moisés (Ex 2, 1-10), en que su madre y su hermana, dos mujeres hebreas, y la hija del faraón y sus doncellas, mujeres egipcias, juntas salvan a un niño hebreo condenado por el decreto infanticida del monarca. En este texto, las mujeres del pueblo oprimido y del pueblo opresor se unen para salvar una vida. 
del pueblo de la esclavitud (Porcile 2008, p. 141). "Las parteras demuestran el coraje de las mujeres para subvertir la opresión representada por el faraón” (Pixley, 2010, p. 182).

Ellas se niegan a aceptar las órdenes del faraón, un opresor, y se unen solidariamente para proteger la vida. En todo caso, prefieren obedecer a otro soberano. No temen en mentir para salvar vidas y su accionar "el primer acto de 'desobediencia civil' de la Historia de Salvación” (Porcile, 2008, p. 139).

La ausencia de su recuerdo plantea algunos interrogantes: ¿̨no se las consideró por ser mujeres y por tanto no se narró su epopeya?, ¿quedaron opacadas por los personajes de los textos anteriores y posteriores (José y Moisés)? o ¿̨hubo algún prejuicio machista o solo un olvido ingenuo?

Este trabajo ha querido rescatar del olvido las figuras de Sifrá y Puá, dos simples comadronas que enfrentan, con valentía y fe, a un déspota. En las parteras, observamos cientos de mujeres y hombres que defienden la vida, y ponen la propia en riesgo, en situaciones de muerte: guerra, persecución, opresión, miseria, etc.

Su epopeya heroica cobra gran significado y vigencia frente a los grandes exterminios de todas las épocas, pero de modo particular a los del siglo pasado: el genocidio armenio, la Shoá, las matanzas étnicas, etc. Ellas nos dan un ejemplo de lucha, entereza, valor y amor a Dios y al prójimo. Como se señaló, no deja de desconcertar la poca recepción de su figura en la Sagrada Escritura, la cual, en muchos casos, es suplida por la recepción y el desarrollo rabínico.

Con dolor, se puede constatar que el faraón sigue vivo, condenando a muerte a muchos nińos en el vientre de su madre, y fuera de él, esta vez sin distinguir sexo, raza o condición social. Pero también, con alegría, se puede afirmar que Sifrá y Puá siguen obrando en tantísimos hombres y mujeres de buena voluntad, que luchan y hacen todo lo posible para seguir honrando al Dios de la vida, y defendiendo, justamente, lo que Él más ama, la vida.

Yaveh es un Dios de la vida con la mediación de quienes quieran, seria, honestamente y también, por qué no, martirialmente, defenderla. Y en el horizonte infinito la descendencia, la fecundidad del Pueblo de Dios.

\section{Referencias}

Agua Pérez, A. del. (1985). El método midrásico y la exégesis del Nuevo Testamento. Institución San Jerónimo para la Investigación Bíblica.

Alonso Schökel, L. (1994). Diccionario biblico hebreo-español. Trotta.

Andiñach, P. R. (2006). El Libro del Éxodo. Sígueme.

Arana, M. J. (2006). Mujeres y espiritualidad de la resistencia. En P. de Miguel Fernández (ed.), Espiritualidady fortaleza femenina (pp. 79-124). Desclée de Brouwer. 
Sifrá y Puá: valientes, rebeldes y sabías heroínas. La figura y el accionar de las parteras en Ex 1, 15-22

Barnawi, N., Richter, S. y Habib, F. (2013). Midwifery and midwives: A historical analysis. Journal of Research in Nursing and Midwifery, 2(8), 114-121.

Barroso, A. (2006). Mujeres, resistencia y vida cotidiana. En P. de Miguel Fernández (ed.), Espiritualidad y fortaleza femenina (pp. 165-200). Desclée de Brouwer.

Calés, M. (dir.) (2004). El talmud de Babilonia: Tratados Nazir-Sota. Acervo Cultural.

Cassuto, U. (1967). A commentary on the book of Exodus. Magnes Press.

Childs, B. S. (1965). The birth of Moses. Journal of Biblical Literature, 84(2), 109-122. https://doi.org/10.2307/3264132

Childs, B. S. (2000). El libro del Éxodo. Verbo Divino.

Ebeling, J. R. (2010). Women's lives in biblical times. T\&T Clark.

Exum, J. C. (1983). "You shall let every daughter live": A study of exodus 1: 8-2: 10. Semeia, 28, 63-82.

Flavio Josefo. (1961). Obras completas. Vol. 1: Vida. Antigüedades judias. Libros I-VI. Acervo Cultural.

García Bachmann, M. (1999). ¿Qué hacían mientras tanto las mujeres hebreas (Éxodo 1-2)? Cuaderno de Teología, 18, 7-19.

Ginzberg, L. (1980). The Legends of the Jews. The Jewish Publication Society of America.

Girón Blanc, L. F. (1989). Midrás Éxodo Rabbah (vol. 1). Institución San Jerónimo para la Investigación Bíblica.

Hasan, I., Zulkifle, M., Ansari, A. H., Sherwani, A. M. K. y Shakir, M. (2011). History of ancient egyptian obstetrics \& gynecology: A review. Journal of Microbiology and Biotechnology Research, 1(1) 35-39.

Henao, J. A. (2011). El actuar yahvista de las mujeres de Egipto. Cuestiones Teologicas, 38(90), 377-400. https:// revistas.upb.edu.co/index.php/cuestiones/article/view/5343

Janssen, R. (2018). A new reading of shiphrah and puah: Recovering their voices. Feminist Theology, 27(1), 9-25. https://doi.org/10.1177/0966735018789129

Johnson, E. A. (2009). La que es: El misterio de Dios en el discurso teológico feminista. Herder.

Langston, S. M. (2006). Exodus through the Centuries. Blackwell. https://doi.org/10.1002/9780470773604

Lattus, J. y Carreño, E. (2010). El asiento del nacimiento. Revista de Obstetricia y Ginecología Hospital Santiago Oriente Dr. Luis Tisné Brousse, 5(1) 41-50.

León Azcárate, J. L. de. (2011) "Yo soy Yahvé, el que te sana" (Ex 15, 26): Enfermedad y salud en la Torá". Theologica Xaveriana, 61(171), 65-96.

Leon-Dufour, X. (1990). Vocabulario de teología biblica. Herder.

Martínez Saiz, T. y Pérez Fernández, M. (2011). Traducciones arameas de la Biblia: Los targumin del Pentateuco. Verbo Divino.

McGeough, K. (2006). Birth bricks, potter's wheels, and exodus 1, 16. Biblica, 87(3) 305-318.

Morschauser, S. (2003). Potters' wheels and pregnancies: A note on exodus 1: 16. Journal of Biblical Literature, 122(4), 731-733. https://doi.org/10.2307/3268074

Ndjerareou, A. (2010). Êxodo. En T. Adeyemo (ed.), Comentario biblico africano (pp. 87-130). Mundo Cristão. 
Pixley, J. (2010). Liberation criticism. En T. B. Dozeman (ed.). Methods for Exodus (pp. 131-162). Cambridge University Press. https://doi.org/10.1017/CBO9780511811142.006

Pontificia Commissio pro Nova Vulgata Bibliorum (1979). Nova Vulgata Bibliorum Sacrorum. Libreria Editrice Vaticana.

Porcile Santiso, M. T. (2008). Con ojos de mujer: Lo femenino en la teologia y en la espiritualidad contemporánea. Claretiana.

Real Academia Española. (2014). Diccionario de la lengua española. Espasa-Calpe.

Römer, T. (2015). Moses and the Women in Exodus 1-4. Indian Theological Studies, 52(3), 237-250.

Roth, A. M. y Roehrig, C. H. (2002). Magical bricks and the bricks of birth. The Journal of Egyptian Archaeology, 88(1), 121-139. https://doi.org/10.1177/030751330208800109

Sheriffs, D. (1990). Moving on with God: Key motifs in Exodus 13-20. Themelios, 15(2), 1-2. http://www. gospelstudies.org.uk/biblicalstudies/pdf/themelios/exodus_sheriffs.pdf

Siebert-Hommes, J. (2010). Las salvadoras del liberador de Israel: Doce "hijas" en Éxodo 1 y 2. En M. Navarro e I. Fische Puerto (eds.), La Torah (pp. 305-321). Verbo Divino.

Ska, J. L. (2006). Il diritto e la legge: Una distinzione fondamentale nella Bibbia. La civiltà cattolica, 157(3737), 468-479.

Töpfer, S. (2014). The physical activity of parturition in ancient Egypt: Textual and epigraphical sources. Dynamis, 34(2), 317-335. https://doi.org/10.4321/S0211-95362014000200003

Vaux, R. de. (1974). Historia antigua de Israel. Vol. 1: Desde los origenes a la entrada de Canaan. Cristiandad.

Weems, R. J. (1992). The hebrew women are not like the egyptian women: The ideology of race, gender and sexual reproduction in Exodus 1. Semeia, 59, 25-34.

Wicke, D. W. (1982). The literary structure of Exodus 1: 2-2: 10. Journal for the Study of the Old Testament, 7(24), 99-107. https://doi.org/10.1177/030908928200702407 